\title{
Pemberdayaan Dalam Perspektif Al-Quran
}

\author{
Masrul Efendi Umar Harahap \\ Fakultas Dakwah dan Ilmu Komunikasi IAIN Padangsidimpuan \\ (E-mail: harahapmasrulefendiumar@gmail.com)
}

\begin{abstract}
Da'wah as one of the ways in community empowerment efforts, has many advantages because it does not study from the perspective of religion alone, but examines from various sources that can be used. Empowerment in the Koran includes economic fields such as through donations, alms, almsgiving, environmental empowerment, education, social, environment and so on. Islam teaches its people through the Qur'an. Islam teaches its people to look after each other, strengthen, educate for world life and the hereafter happiness. If seen empowerment in the context of da'wah then there are 4 functions of da'wah relating to empowerment, namely: i'tiyadi, muharriq, iqaf, and tahrif.
\end{abstract}

Keyword: Empowerment, Al-Quran.

Abstrak: Dakwah merupakan sebuah upaya pemberdayaan masyarakat yang memiliki banyak keunggulan, karena tidak belajar dari perspektif agama semata, tetapi mengkaji dari berbagai sumber yang dapat digunakan. Didalam Al-Qur'an Pemberdayaan meliputi bidang ekonomi seperti melalui donasi, sedekah, pendidikan, sosial, lingkungan dan sebagainya. Islam juga mengajarkan umatnya untuk saling menjaga, menguatkan, mendidik kehidupan dunia dan kebahagiaan akhirat. Jika dilihat pemberdayaan dalam konteks dakwah maka ada 4 fungsi dakwah yang berkaitan dengan pemberdayaan, yaitu: i'tiyadi, muharriq, iqaf, dan tahrif.

Katakunci: Pemberdayaan, Al-Quran. 
98 Masrul Effendi Umar Harahap, Pemberdayaan Dalam Perspektif Al-Quran Jurnal At-Taghyir : Jurnal Dakwah dan Pengembangan Masyarakat Desa

Volume 2 Nomor 1 Desember 2019, h. 97-112

\section{A. Pendahuluan}

Pemberdayaan merupakan sebuah upaya pembangunan alternatif terhadap teori modernisasi yang lahir setelah perang dunia ke-II. Modernisasi selain menghasilkan kemajuan juga turut menyumbangkan berbagai masalah. Masalah yang ada muncul dari berbagai aspek, baik dari aspek ekonomi, sosial, politik dan budaya. Hal ini wajar terjadi ketika masyarakat menganggap modernisasi merupakan sebuah kemajuan dan tidak semua orang yang bisa memamfaatkannya secara positif. Inilah pemicu terjadinya berbagai permasalahan sosial yang ada dalam masyarakat.

Mukti Ali mengatakan bahwa untuk mengantisipasi dampak negatif dari modernisasi dapat dilakukan dengan cara yang Islami. ${ }^{1}$ Pengertian yang dimaksud adalah dengan memberikan kontribusi terhadap keragaman budaya dalam hal pengaktualisasian nilai-nilai ajaran agama Islam, dan menyaring modrenitas itu sendiri dengan melaksanakan apa yang sesuai dengan syariat dan meninggalkan yang tidak sesuai dengannya. ${ }^{2}$ Salah satu usaha yang bisa dilakukan adalah melalui pemberdayaan masyarakat dengan harapan masyarakat mampu mengembangkan kemampuannya, mengubah prilakunya serta mampu mengorganisir berbagai permasalahan yang dihadapinya.

\section{B. Pemberdayaan Masyarakat}

Menurut Suharto dalam buku Sosiologi Perubahan Sosial, empowerment atau pemberdayaan diambil dari kata "power" (kekuatan/kemampuan). Merujuk kepada pengertian tersebut permberdayaan tidak terlepas dari sebuah kekuatan dan kemampuan yang dimiliki seseorang. Pengertian tersebut juga dapat dikaitkan dengan sebuah kekuasaan yang dimiliki seseorang dalam memenuhi keinginannya memalui orang lain. ${ }^{3}$ Bila dikaitkan dengan konsep pemberdayaan maka kekuasaan tersebut merupakan kemampuan yang dimiliki seseorang dalam mewujudkan keinginan melalui kekuatan yang dimilikinya, begitu juga kewajiban-kewajiban yang harus ia kerjakan. Masyarakat dalam bahasa Inggris disebut society, diambil dari kata socius yang diartikan sebagai kawan. ${ }^{4}$ Di dalam bahasa Arab masyarakat disebut dengan as-syirk yang berarti serikat,

\footnotetext{
${ }^{1}$ Mukti Ali, Agama Dalam Pergumulan Masyarakat Kontemporel, (Yogyakarta : Tiara Wacana Yogya), hlm.142

${ }^{2}$ Mukti Ali, Agama Dalam Pergumulan Masyarakat Kontemporel..., hlm.142.

${ }^{3}$ Nanang, Sosiologi Perubahan Sosial, (Jakarta : PT. Raja Grafindo, 1998), hlm. 261

${ }^{4}$ Munandar Soeleman, Ilmu Sosial Dasa, (Bandung: PT. Eresco, 1993), hlm. 63
} 
99 Masrul Effendi Umar Harahap, Pemberdayaan Dalam Perspektif Al-Quran Jurnal At-Taghyir : Jurnal Dakwah dan Pengembangan Masyarakat Desa Volume 2 Nomor 1 Desember 2019, h. 97-112

bekerja sama. Kemudian dalam Kamus Besar Bahasa Indonesia masyarakat memiliki arti sebuah kelompok manusia yang memiliki adat atau budaya yang dibangun oleh kelompok masyarakat itu sendiri dalam menjalankan aktivitas sehari-hari. ${ }^{5}$ Bila dilihat dari penjelasan di atas maka pemberdayaan masyarakat adalah sebuah pembangunan masyarakat dalam bidang ekonomi yang mengandung nilai-nilai sosial. Paradigma pembangunan seperti ini yang disebut dengan pembangunan bersifat, people centered, participatory, empowering dan sustainable. ${ }^{6}$

Dari penjelasan di atas penulis menyimpulkan bahwa pemberdayaan masyarakat merupakan sebuah upaya yang dilakukan untuk mewujudkan kehidupan yang lebih baik dari sebelumnya ataupun yang disebut peningkatan kesejahteraan. Maka masyarakat yang berdaya adalah masyarakat yang mampu membuat sebuah keputusan yang tepat dalam menghadapi berbagai persoalan hidup dan tidak bergantung kepada orang lain, dalam istilah lain mampu mengubah sebuah keadaan yang yang kurang baik menjadi keadaan yang lebih baik dengan solusi-solusi cemerlang yang dimiliki. Dengan bermacan corak pemberdayaan yang ada, bila dirujuk pada kebijakan-kebijakan yang sudah dibuat dapat dilihat dari tiga hal, yaitu: ${ }^{7}$

1. Pada tahun 1970 hingga tahun 1990 -an pemberdayaan menjadi sebuah solusi dalam hal pembangunan.

2. Kebijakan pemerintah yang tidak pro terhadap rakyat menjadi sebuah masalah serius yang bisa dituntaskan melalui sebuah pemberdayaan.

3. Kemiskinan, pengangguran, masyarakat tertinggal dan lain sebagainya teratasi dengan sebuah pemberdayaan. ${ }^{8}$

Ketiga kebijakan tersebut di atas menjadi dasar yang kuat bagi seorang agen of change dalam menjalankan sebuah misi pemberdayaan masyarakat yaitu menjadikan pemberdayaan sebagai solusi yang tepat dalam menangani berbagai permasalahan yang ada di tengah-tengah masyarakat. Namun perlu disadari bahwa proses pemberdayaan bukanlah hal yang mudah dilaksanakan, karena berkaitan dengan kebiasaan atau budaya masyarakat, perlu adanya sebuah analisa yang baik dalam mencari sebuah solusi-solusi

\footnotetext{
${ }^{5} \mathrm{KBBI}$ v1.1

${ }^{6}$ Chambers, 1995 dalam Kartasasmita, 1996

7 Randhi Wrihatnolo, Manajemen Pemberdayaan Masyarakat, (Jakarta(Jakarta : PT. Elex Media Komputindo, 2007), hlm. 29-32

${ }^{8}$ Randhi Wrihatnolo, Manajemen Pemberdayaan Masyarakat..., hlm. 29-32
} 
100 Masrul Effendi Umar Harahap, Pemberdayaan Dalam Perspektif Al-Quran Jurnal At-Taghyir : Jurnal Dakwah dan Pengembangan Masyarakat Desa

Volume 2 Nomor 1 Desember 2019, h. 97-112

yang tepat. Kemudian dalam pemberdayaan ada tiga tahap yang harus dilalui yaitu, penyadaran, pengkapasitasan dan pendayaan, dan tahapan tersebut harus dilaksanakan secara maksimal dan berkesinambungan guna mendapatkan hasil yang maksimal pula.

Pemberdayaan masyarakat sebagai suatu usaha yang digambarkan dalam berbagai bentuk kegiatan yang nyata di tengah masyarakat. Pemberdayaan pada hakikatnya adalah upaya peningkatan kualitas maupun kuantitas kehidupan manusia. Pemberdayaan juga berarti perubahan masyarakat kearah yang lebih baik, dalam rangka mencapai tujuan yang dicita-citakan yaitu meningkatkan taraf hidup, kemakmuran, dan kesejahteraan seluruh rakyat baik materil maupun spiritual. Dari beberapa pendapat di atas dapat dimengerti bahwa yang dimaksud pemberdayaan masyarakat adalah suatu usaha yang digambarkan dalam berbagai bentuk kegiatan yang nyata di tengah masyarakat. Tujuan pemberdayaan adalah menyadarkan masyarakat agar dapat menggunakan serta memilih kehidupannya untuk mencapai tingkat hidup yang lebih baik dalam segala segi kehidupan.

Dalam perspektif Islam dikutip dari pendapat M. Quraish Sihab pemberdayaan sifatnya harus kaffah (menyeluruh), menyentuh dan membeku dalam diri manusia, dengan tujuan agar manusia bisa berubah secara utuh dari segala aspek yang ada seperti materil dan spritualnya. ${ }^{9}$ Materil dan spiritual yang dimaksud adalah bagian yang tidak terpisahkan dari diri manusia, karena keduanya memiliki wadah yang bersamaan.

Di sisi lain bila dikaitkan dengan dakwah keduanya sama-sama memiliki tujuan yang sama yaitu, sebuah upaya yang dilakukan untuk sebuah perubahan masyarakat yang lebih baik. Seperti yang diungkapkan oleh Muhammad Sulthon dalam bukunya bahwa fungsi dakwah dilihat targetnya. Adapun fungsi dakwah tersebut dibedakan kepada empat hal, yaitu: ${ }^{10}$

1. I'tiyadi, yaitu tatana nilai dalam sebuah masyarakat yang diikat oleh nilai-nilai Islami, maka dakwah disini harus dilaksanakan sesuai dengan ajaran Islam agar tata nilai itu kembali kepada yang sesuai dengan nilai-nilai keislaman.

${ }^{9}$ M. Qureish Shihab, Membumikan Al-Qur'an:Fungsi dan peran wahyu Dalam Masyarakat, (Bandung : Mizan, 2004), Cet.Ke-18, hlm. 301

${ }^{10}$ Muhammad Sulthon, Desain Ilmu Dakwah, Kajian Ontologis, Epistemologis dan Aksiologis, (Semarang : Wali Songo Press, 2003), hlm.140-141 
101 Masrul Effendi Umar Harahap, Pemberdayaan Dalam Perspektif Al-Quran Jurnal At-Taghyir : Jurnal Dakwah dan Pengembangan Masyarakat Desa Volume 2 Nomor 1 Desember 2019, h. 97-112

2. Muharriq, yaitu target dakwah yang sudah memiliki tatanan nilai-nilai Islami harus lebih ditingkatkan.

3. Iqaf, petunjuk ataupun peringatan-peringatan yang disampaikan kepada masyarakat harus relevan dengan kondisi riil agar masyarakat tidak salah dalam mengamalkan nilai-nilai keislaman itu sendiri.

4. Tahrif, yaitu dakwah yang disampaikan harus benar-benar sesuai dengan kondisi masyarakat yang memiliki barbagai persoalan hidup.

5. Tahrif, dakwah yang dilakukan merupakan sebuah usaha dalam memberikan solusi terhadap masalah-masalah yang terjadi di tengah-tengah masyarakat. ${ }^{11}$

Keempat fungsi dakwah di atas memiliki kaitan dengan usaha pemberdayaan seperti setiap orang harus mampu berkembang dalam kehidupannya, menjaga persatuan agar tidak terpuruk oleh pengaruh yang tidak baik. Kemudian adanya upaya untuk membantu meringankan masalah- masalah yang mempersulit kehidupan. Intinya untuk mempermudah kehidupan bermasyarakat dan mampu menyelesaikan segera bentuk persoalannya. Melihat fungsi dakwah di atas, bila dikaitkan dengan fungsi pemberdayaan tentu tidak ada perbedaan yaitu sama-sama memberikan tuntunan kepada masyarakat untuk mampu menyelesaikan persoalan-persoalan yang terjadi di masyarakat, seperti tidak larut dalam kesusahan atau hal-hal yang membuat masyarakat tidak memiliki semangat hidup. Namun masyarakat harus yakin dengan kemampuannya dan memiliki harapan yang baik di masa depan.

\section{Pemberdayaan Masyarakat dalam Al-Quran}

Apabila ditelusuri seluruh sisi kehidupan manusia sudah dibahas di dalam AlQuran. Walaupun pembahasannya terkadang hanya dalam bentuk mujmal. Seperti dalam hal hubungan terhadap manusia (hablumminannas) dan juga hubungan kepada Allah (hablumminalloh). Allah menjadikan manusia di bumi sebagai pemimpin yang diberikan tanggung jawab untuk memelihara kehidupan di dunia, dalam Al-quran surat Al-Baqarah ayat 30 disebutkan:

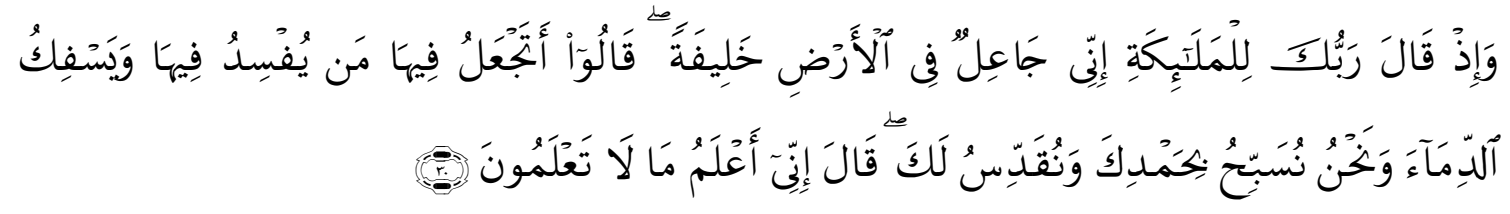

${ }^{11}$ Muhammad Sulthon, Desain Ilmu Dakwah, Kajian Ontologis..., hlm.140-141 
102 Masrul Effendi Umar Harahap, Pemberdayaan Dalam Perspektif Al-Quran Jurnal At-Taghyir : Jurnal Dakwah dan Pengembangan Masyarakat Desa

Volume 2 Nomor 1 Desember 2019, h. 97-112

"Ingatlah ketika Tuhanmu berfirman kepada para malaikat: "Sesungguhnya Aku hendak menjadikan seorang khalifah di muka bumi." mereka berkata: "Mengapa Engkau hendak menjadikan (khalifah) di bumi itu orang yang akan membuat kerusakan padanya dan menumpahkan darah, padahal kami senantiasa bertasbih dengan memuji Engkau dan mensucikan Engkau?" Tuhan berfirman: "Sesungguhnya aku mengetahui apa yang tidak kamu ketahui."

Ayat di atas menerangkan bahwasanaya Allah menyerahkan kepemimpinan di dunia kepada manusia. Kepemimpinan ini dalam arti memelihara, menata dan mengatur seluruh aktivitas manusia dalam kehidupan sehingga kehidupannya menjadi lebih baik. ${ }^{13}$ Oleh karena itu di antara penjelasan Al-Quran yang paling penting adalah tentang memberdayakan masyarakat agar manusia menjadi lebih baik. Beberapa bidang pemberdayaan yang ada dalam al-Qur'an, di antaranya:

1. Pemberdayaan Masyarakat di Bidang Pendidikan

Pendidikan pada umumnya bertujuan untuk meningkatkan taraf hidup masyarakat. Pendidikan yang baik akan sangat tepat dalam mengatasi persoalan kemiskinan, memperbaiki sebuah demokrasi yang buruk dan menciptakan masyarakat sejahtera. ${ }^{14}$ Islam menyadari hal yang demikian, sehingga al-Quran yang merupakan pedoman hidup umat muslim mendorong kaum muslimin untuk belajar dan menuntut ilmu.

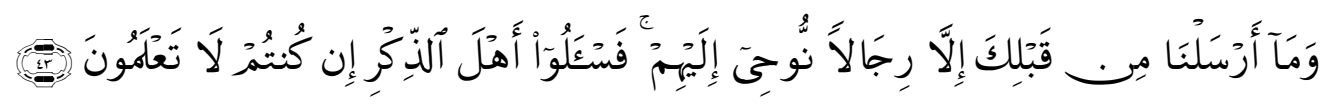

"Dan Kami tidak mengutus sebelum kamu, kecuali orang-orang lelaki yang Kami beri wahyu kepada mereka; Maka bertanyalah kepada orang yang mempunyai pengetahuan jika kamu tidak mengetahui."

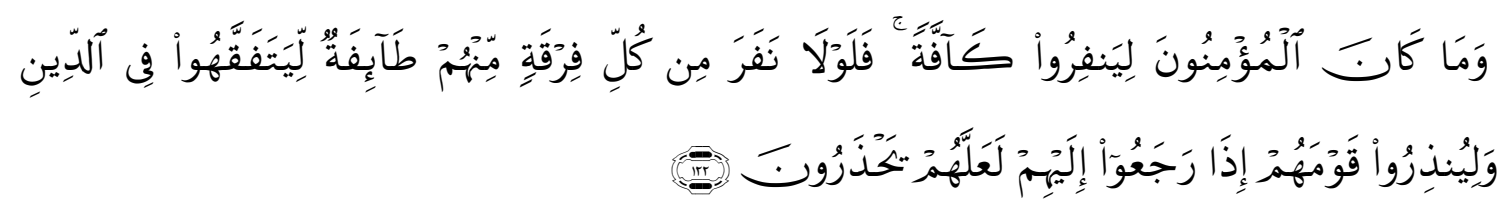

\footnotetext{
${ }^{12}$ QS. Al-Baqoroh Ayat 30

${ }^{13}$ Sayyid Quthb, Fi Zhilalili Quran, (Beirut: Dar Syurq, 1412H), hlm. 55

${ }^{14}$ Lihat dalam, Dr. Affizal Ahmad, kepentingan Pendidikan dalam Pembentukan Kualitas Hidup Sejahtera, (Malaysia : Universiti Sains Malaysia, 2010), hlm. 2

${ }^{15}$ QS. An-Nahl ayat 43
} 
103 Masrul Effendi Umar Harahap, Pemberdayaan Dalam Perspektif Al-Quran Jurnal At-Taghyir : Jurnal Dakwah dan Pengembangan Masyarakat Desa

Volume 2 Nomor 1 Desember 2019, h. 97-112

"Tidak sepatutnya bagi mukminin itu pergi semuanya (ke medan perang). mengapa tidak pergi dari tiap-tiap golongan di antara mereka beberapa orang untuk memperdalam pengetahuan mereka tentang agama dan untuk memberi peringatan kepada kaumnya apabila mereka telah kembali kepadanya, supaya mereka itu dapat menjaga dirinya."16

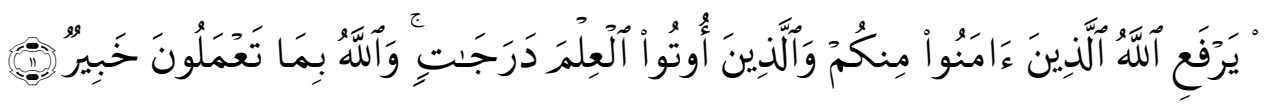

"Allah akan meninggikan orang-orang yang beriman di antaramu dan orang-orang yang diberi ilmu pengetahuan beberapa derajat. dan Allah Maha mengetahui apa yang kamu kerjakan. $^{17}$

Negara-negara maju sangat memperhatikan pendidikan karena mereka menyadari pendidikan menjadi alat utama dalam meningkatkan kesejahteraan mereka. Pendidikan akan menciptakan masyarakat yang madani dan sejahtera. ${ }^{18}$ Pendidikan merupakan suatu usaha untuk mendapatkan ilmu. Wawasan diperluas dengan berbagai informasi yang bisa diperoleh melalui dunia pendidikan. Islam juga memerintahkan umatnya untuk berilmu, ilmu adalah penopang amal.

2. Pemberdayaan Masyarakat dalam Bidang Sosial

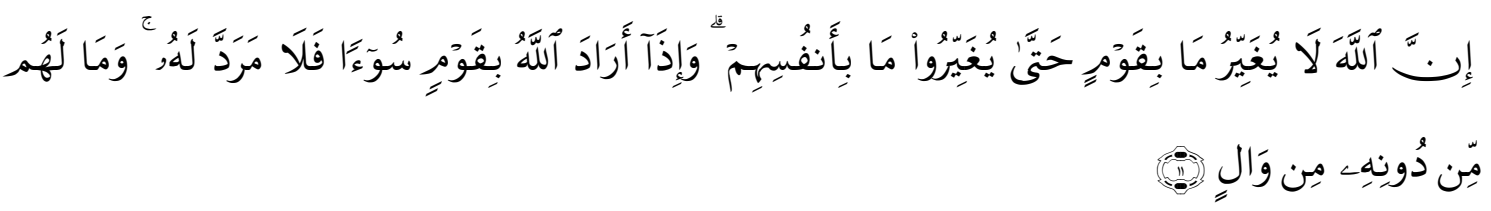

"Sesungguhnya Allah tidak merobah Keadaan sesuatu kaum sehingga mereka merobah keadaan yang ada pada diri mereka sendiri, dan apabila Allah menghendaki keburukan terhadap sesuatu kaum, Maka tak ada yang dapat menolaknya; dan sekali-kali tak ada pelindung bagi mereka selain dia." 19

Memberdayakan masyarakat merupakan tanggung jawab yang tidak hanya bisa dilakukan oleh satu individu saja. Akan tetapi, pemberdayaan akan berhasil apabila dilakukan secara kolektif atau bersama-sama. Surat Ar-Ra`d ayat 11 menjelaskan bahwa masyarakat madani hanya bisa diwujudkan melalui komunikasi antar masyarakat yang

${ }^{16}$ QS. At-Taubah Ayat 122

${ }^{17}$ QS. Al-Mujadilah Ayat 11

${ }^{18}$ Marx, K, Early Writings, (New york : McGraw- Hill, 1964), Lihat dalam Dr. Affizal Ahmad, kepentingan Pendidikan dalam Pembentukan Kualitas Hidup Sejahtera, (Malaysia : Universiti Sains Malaysia, 2010)

${ }^{19}$ QS Ar-Ra'du Ayat 11 
104 Masrul Effendi Umar Harahap, Pemberdayaan Dalam Perspektif Al-Quran Jurnal At-Taghyir : Jurnal Dakwah dan Pengembangan Masyarakat Desa

Volume 2 Nomor 1 Desember 2019, h. 97-112

ingin melakukan perbaikan karena kemakmuran suatu masyarakat hanya dapat diwujudkan melalui perubahan secara masal dan berkesinambungan. Oleh Karena itu ketika masyarakat memiliki satu tujuan dan siap melakukan aksi bersama untuk mewujudkan tujuan yang diinginkan yaitu untuk menciptakan masyarakat yang makmur.

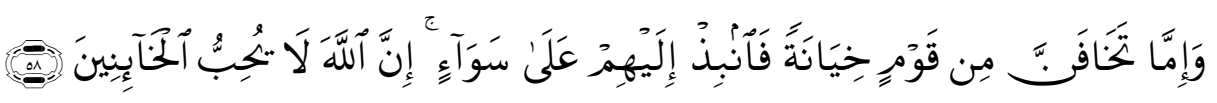

"Dan jika kamu khawatir akan (terjadinya) pengkhianatan dari suatu golongan, Maka kembalikanlah Perjanjian itu kepada mereka dengan cara yang jujur. Sesungguhnya Allah tidak menyukai orang-orang yang berkhianat. ${ }^{20}$

Allah menciptakan dunia sebagai tempat manusia mencari bekal akhirat. Bersungguh-sungguh menjalani kehidupan di dunia merupakan awal dari kebahagiaan yang akan kita dapatkan di akhirat. Untuk mengantisipasi sebuah keburukan dalam masyarakat maka harus diadakan perjanjian yang akan menjaga kesatuan masyarakat. Kenyaman individu baru terjadi ketika berada dalam kondidi sosialyang aman pula. Ini yang sering kali terabaikan. Manusia saat ini lebih mementingkan kehidupan individu dibandingkan kehidupannya dalam bermasyarakat. Hal ini harus diubah karena keduanya mempunyai kaitan yang sangat erat dan saling mempengaruhi.

3. Pemberdayaan Masyarakat melalui pemeliharaan lingkungan.

Allah Swt menciptakan manusia dan alam sebagai sesuatu yang saling berhubungan. Di dalam al-Qur'an banyak dijelaskan mengenai alam semesta. Bagaimana Allah Swt menjadikan alam ini sebagai sarana berfikir akan kekuasaan dan kebenaran Allah sebagai Sang Pencipta. Alam disediakan oleh Allah untuk manusia supaya manusia bisa menjalani kehidupan. Alam menjadi bagian yang penting dari pemberdayaan masyarakat.

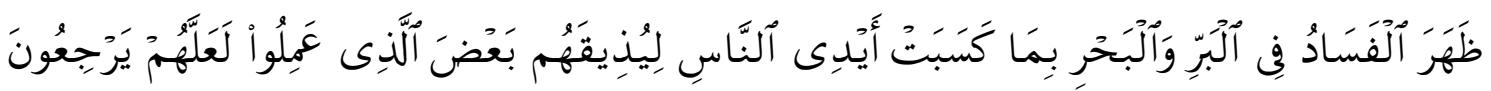

\footnotetext{
${ }^{20}$ QS. Al-Anfal Ayat 58
} 
105 Masrul Effendi Umar Harahap, Pemberdayaan Dalam Perspektif Al-Quran Jurnal At-Taghyir : Jurnal Dakwah dan Pengembangan Masyarakat Desa

Volume 2 Nomor 1 Desember 2019, h. 97-112

"Telah nampak kerusakan di darat dan di laut disebabkan karena perbuatan tangan manusi, supay Allah merasakan kepada mereka sebahagian dari (akibat) perbuatan mereka, agar mereka kembali (ke jalan yang benar)." 21

Semua yang diciptakan selalu memberi manfaat bagi manusia. Alam dan segala isinya diperuntukkan untuk kemaslahatan manusia yang selalu harus menjaga lingkungannya dari kerusakan. Kerakusan seringkali membuat manusia lupa bahwa alam juga harus dijaga. Misalnya kelestarian hutan, kebersihan air, menjaga kebersihan udara, merupakan bentuk kecintaan kepada lingkungan. Lingkungan yang sehat akan mempengaruhi yang ada di sekitarnya.

4. Pemberdayaan Masyarakat di Bidang Ekonomi

Di antara strategi al-Quran untuk memberdayakan masyarakat adalah dengan berinfaq. Tidak diragukan lagi bahwa al-Quran dengan strategi infak akan membangun sistem ekonomi sosial dengan memadukan dua unsur yang paling mendasar. Pertama, pengakuan terhadap pemeberian hak individu dalam memperoleh hasil dari pekerjaannya, dan tidak membatasi kebebasan bekerja selama pekerjaan itu kekal, baik, tidak ada unsur dosa dan permusuhan. Ini adalah akses yang dibangun oleh sistem ekonomi modern yang dinamakan kapitalisme. Namun sistem ini tidak mampu memperbaiki dan melestarikan kehidupan sosial yang berkualitas dan bersih. Oleh karena itu, asas ini harus dipadukan dengan asas kedua, yaitu pengakuan hak social dalam hak individu, dan kewajiban saling menjamin (solidaritas) masing-masing individu. Al-Quran diturunkan dalam membawa misi kesatuan dua asas atau sistem ekonomi ideal yang bertujuan untuk mensejahterakan masyarakat Islam. ${ }^{22}$

a. Pemberdayaan Masyarakat melalui infak

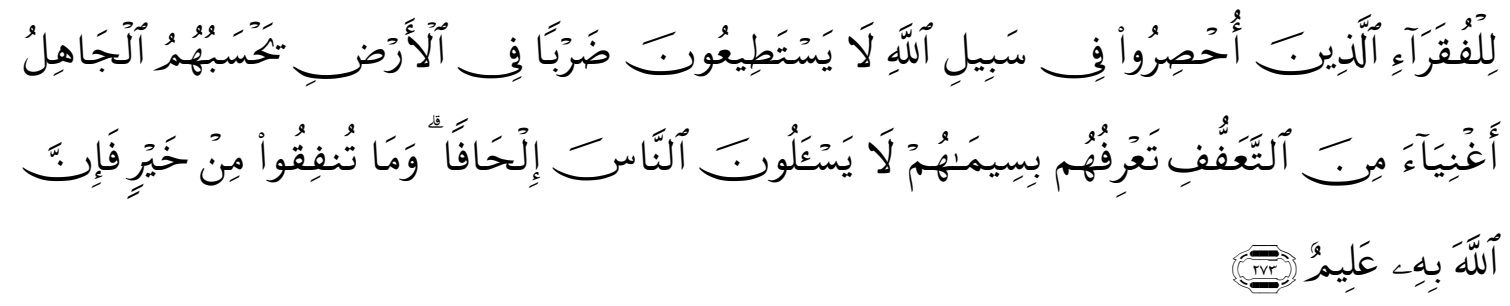

"(Berinfaqlah) kepada orang-orang fakir yang terikat (oleh jihad) di jalan Allah; mereka tidak dapat (berusaha) di bumi; orang yang tidak tahu menyangka mereka orang Kaya

\footnotetext{
${ }^{21}$ QS Ar-Rum Ayat: 41

22 Jama`ah Amin Abdul Aziz, Wasiat Qurani Aktivis Dakwah, (Jogjakarta: Uswah, 2007 M), hlm. 412
} 
106 Masrul Effendi Umar Harahap, Pemberdayaan Dalam Perspektif Al-Quran Jurnal At-Taghyir : Jurnal Dakwah dan Pengembangan Masyarakat Desa

Volume 2 Nomor 1 Desember 2019, h. 97-112

karena memelihara diri dari minta-minta. kamu kenal mereka dengan melihat sifatsifatnya, mereka tidak meminta kepada orang secara mendesak. dan apa saja harta yang baik yang kamu nafkahkan (di jalan Allah), Maka Sesungguhnya Allah Maha Mengatahui., 23

Di antara strategi al-Quran dalam mengoptimalkan harta adalah sebagai berikut:

b. Motivasi berinfak fi sabilillah

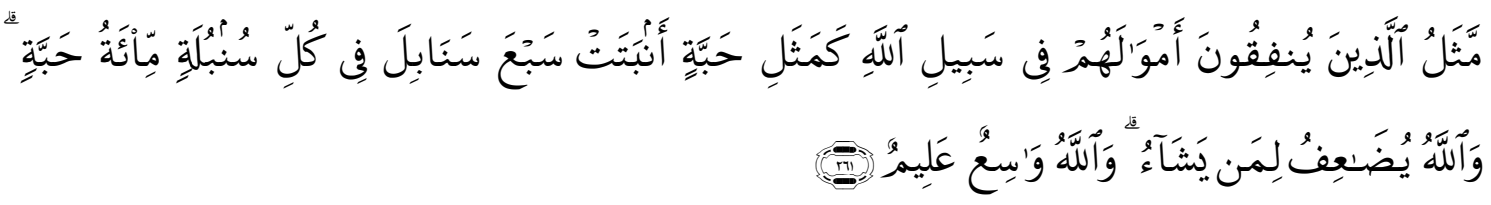

"Perumpamaan (nafkah yang dikeluarkan oleh) orang-orang yang menafkahkan hartanya di jalan Allah[166] adalah serupa dengan sebutir benih yang menumbuhkan tujuh bulir, pada tiap-tiap bulir seratus biji. Allah melipat gandakan (ganjaran) bagi siapa yang Dia kehendaki. dan Allah Maha Luas (karunia-Nya) lagi Maha mengetahui." 24

Ayat ini menjelaskan bahwa balasan untuk orang yang menginfakkan hartanya di jalan Allah adalah dibalas 700 kali lipat. ${ }^{25}$ Ini ditujukan supaya manusia termotivasi untuk berinfak.

c. Ancaman bagi orang-orang yang menimbun harta dan kikir

"Hai orang-orang yang beriman, sesungguhnya sebahagian besar dari orang-orang alim Yahudi dan rahib-rahib Nasrani benar-benar memakan harta orang dengan jalan yang batil dan mereka menghalang-halangi (manusia) dari jalan Allah. Dan orang-orang yang menyimpan emas dan perak dan tidak menafkahkannya pada jalan Allah, maka beritahukanlah kepada mereka, (bahwa mereka akan mendapat) siksa yang pedih, (34) pada hari dipanaskan emas perak itu dalam neraka Jahanam, lalu dibakar dengannya dahi mereka, lambung dan punggung mereka (lalu dikatakan) kepada mereka: "Inilah harta bendamu yang kamu simpan untuk dirimu sendiri, maka rasakanlah sekarang (akibat dari) apa yang kamu simpan itu., 26

Dalam ayat di atas terdapat kata ahbar, dan ruhban. Istilah ahbar digunakan untuk para pemuka agama yahudi sedangkan kata ruhban, digunakan bagi ahli ibadah Nasrani. Kata Bathil yang terdapat dalam ayat diatas berarti bahwa sesungguhnya mereka (ahbar dan ruhban) mengambil harta pengikut-pengikut mereka dalam bentuk pajak atau iuran wajib atas nama gereja dan pelaksanaan syariah. Kemudian mereka

\footnotetext{
${ }^{23}$ QS. Al-Baqoroh Ayat 273

${ }^{24}$ QS. Al-Baqarah: 261

25 Abu Ja`far at-Thabari, Jamiul Bayan fi Tafsiril Quran, (Cairo: Muassasah Risalah, 2000 M), hlm. 531

${ }^{26}$ QS. Taubah: 34-35
} 
107 Masrul Effendi Umar Harahap, Pemberdayaan Dalam Perspektif Al-Quran Jurnal At-Taghyir : Jurnal Dakwah dan Pengembangan Masyarakat Desa

Volume 2 Nomor 1 Desember 2019, h. 97-112

menyembunyikan harta untuk dipergunakan sendiri. Pada ayat selanjutnya Allah menerangkan ganjararan yang didapatkan oleh orang-orang tersebut. ${ }^{27}$

Fokus pada ayat di atas adalah hukuman bagi orang yang menahan atau menyimpan harta dengan cara yang tidak baik. Pada awalnya ayat ini hanya ditujukan kepada kaum Pendeta Nasrani dan Rabi Yahudi, akan tetapi untuk konteks sekarang ayat ini bisa dijadikan landasan bagi seluruh umat manusia yang suka menimbun harta dan kikir.

d. Peringatan agar tidak boros dan anjuran untuk hidup sederhana

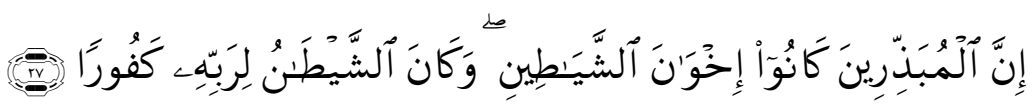

"Sesungguhnya pemboros-pemboros itu adalah saudara-saudara syaitan dan syaitan itu adalah sangat ingkar kepada Tuhannya.,"28

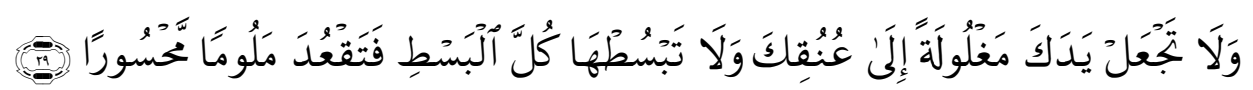

"Dan janganlah kamu jadikan tanganmu terbelenggu pada lehermu dan janganlah kamu terlalu mengulurkannya karena itu kamu menjadi tercela dan menyesal., 29

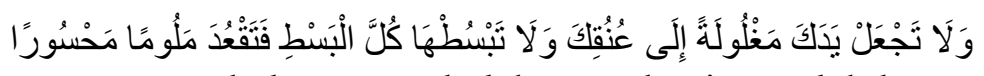

"Dan janganlah kamu jadikan tanganmu terbelenggu pada lehermu dan janganlah kamu terlalu mengulurkannya karena itu kamu menjadi tercela dan menyesal.",30

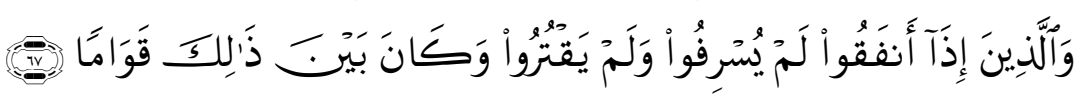

"Dan orang-orang yang apabila membelanjakan (harta), mereka tidak berlebihan, dan tidak (pula) kikir, dan adalah (pembelanjaan itu) di tengah-tengah antara yang demikian., 31

Pada ayat 29 surah Al-Isra' terdapat kalimat "dan janganlah kamu jadikan tanganmu terbelenggu pada lehermu” maksudnya adalah menahan harta atau kikir. Sedangkan kata tabdzir artinya adalah membelanjakan harta pada hal-hal yang tidak baik (menyebabkan kerusakan), atau berlebih-lebihan dalam hal yang dibolehkan. Berlebih-lebihan merupakan perbuatan tercela. Cara yang paling benar dalam membelanjakan harta adalah sederhana dan tidak berlebih-lebihan dalam

27 Imam Qurthubi, Aljami` li Ahkamil Quran, (Cairo: Darul Kutub al Misriyah, 1964 M), hlm. 122

\footnotetext{
${ }^{28}$ QS. Al-Isra': 27

${ }^{29}$ QS. Al-Isra': 29

${ }^{30}$ QS. Al-Isra`: 29

${ }^{31}$ QS. Al-Furqon: 67
} 
108 Masrul Effendi Umar Harahap, Pemberdayaan Dalam Perspektif Al-Quran Jurnal At-Taghyir : Jurnal Dakwah dan Pengembangan Masyarakat Desa

Volume 2 Nomor 1 Desember 2019, h. 97-112

membelanjakan harta. $^{32}$ Sikap ini telah dikecam dalam al-Qur'an dengan tujuan melarang manusia agar tidak bakil dan suka menimbul harta.

e. Mendahulukan yang lebih dekat dalam keluarga dan lebih membutuhkan.

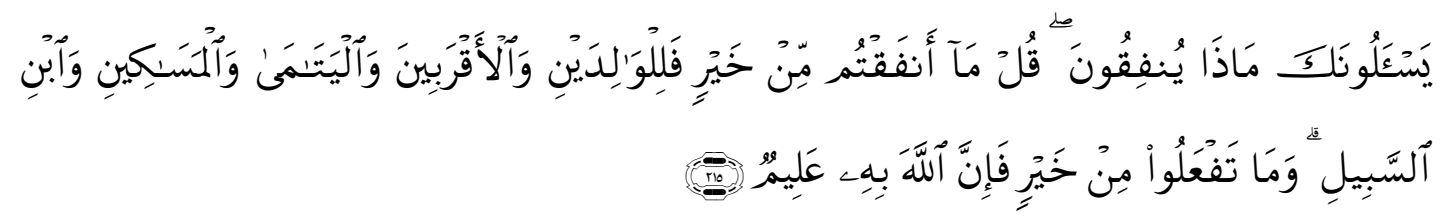

"Mereka bertanya tentang apa yang mereka nafkahkan. Jawablah: "Apa saja harta yang kamu nafkahkan hendaklah diberikan kepada ibu-bapak, kaum kerabat, anak-anak yatim, orang-orang miskin dan orang-orang yang sedang dalam perjalanan." Dan apa saja kebaikan yang kamu buat, Maka Sesungguhnya Allah Maha mengetahuinya."33

Muqatil bin Hayyan berkata : ayat ini membahas tentang sedekah yang sunnah. Kemudian makna ayat :

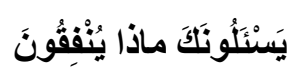

Ibnu Abbas dan Mujahid berkata: Allah menjelaskan bagaimana cara berinfak pada kata setelahnya;

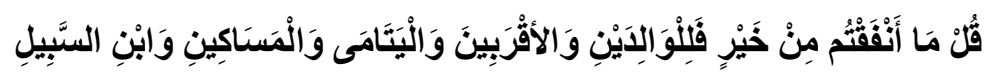

Kalimat ini menunjukkan jawaban dari pertanyaan bagaimana berinfak. Kemudian hal ini dikuatkan oleh hadits: kedua orang tuamu, saudara-saudara terdekatmu, anak-anak yatim, orang miskin dan ibnu sabil. ${ }^{34}$

5. Memelihara anak yatim bagian pemberdayaan masyarakat

Kata yatim terdapat sebanyak 23 kali dalam al-Quran, ${ }^{35}$ dan setiap kata tersebut selalu diiringi oleh kemiskinan, dan ketidakberuntungan. Allah memebebankan tanggung jawab pemeliharan anak yatim kepada umat atau masyarakat, agar mereka terlindungi, belajar dengan tenang, hidup layak dan bergembira seperti anak-anak lain yang memiliki ibu dan ayah.

\footnotetext{
${ }^{32}$ Wahbah Zuhaily, Tafsir al-Washit ,(Damaskus: Darul Fikri, 1422 H), h.1343, Jilid II

${ }^{33}$ QS. Al-Baqoroh: 215

${ }^{34}$ Ibnu Katsir, Tafsir alquran al-adzhim, (Cairo: Dar Thayyibah, 1999), Jilid I, hlm. 572,

${ }^{35}$ Muhammad Fu'ad Abd. al-Baqi,. al-Mu'jam al-Mufahras li al-Fazh al-Qur'an, (Beirut: Dar
} al-Ma'rifah, 1992), hlm. 770 
109 Masrul Effendi Umar Harahap, Pemberdayaan Dalam Perspektif Al-Quran Jurnal At-Taghyir : Jurnal Dakwah dan Pengembangan Masyarakat Desa

Volume 2 Nomor 1 Desember 2019, h. 97-112

Ayat-ayat yang berbicara tentang anak yatim, menjelaskan tanggung jawab masyarakat dalam melindungi mereka, serta membimbing dan mengayomi kehidupan mereka kearah yang lebih baik. Diantara ayat yang menjelaskan hal tersebut antara lain,

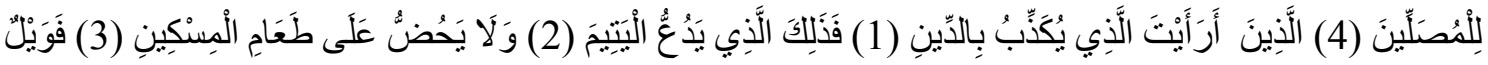

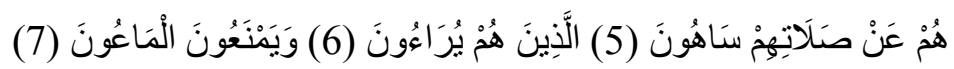

"Tahukah kamu (orang) yang mendustakan agama?(1) Itulah orang yang menghardik anak yatim,(2) dan tidak menganjurkan memberi makan orang miskin.(3) Maka kecelakaanlah bagi orang-orang yang salat,(4) (yaitu) orang-orang yang lalai dari salatnya,(5) orang-orang yang berbuat ria,(6) dan enggan (menolong dengan) barang berguna." $" 36$

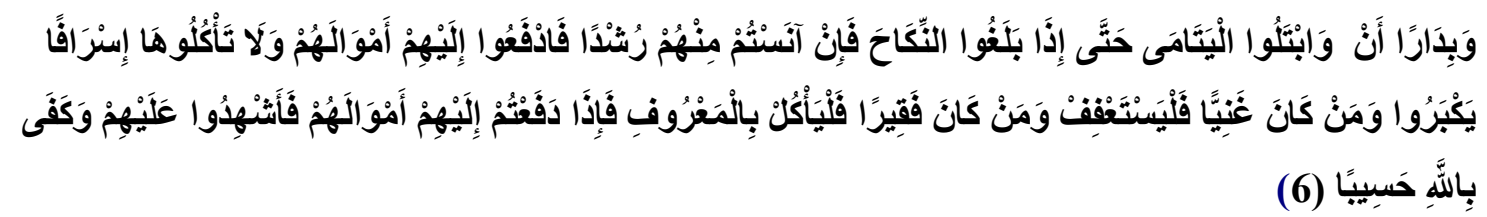

"Dan ujilah anak yatim itu sampai mereka cukup umur untuk kawin. kemudian jika menurut pendapatmu mereka telah cerdas (pandai memelihara harta), maka serahkanlah kepada mereka harta-hartanya. dan janganlah kamu makan harta anak yatim lebih dari batas kepatutan dan (janganlah kamu) tergesa-gesa (membelanjakannya) sebelum mereka dewasa. barang siapa (di antara pemelihara itu) mampu, maka hendaklah ia menahan diri (dari memakan harta anak yatim itu) dan barangsiapa yang miskin, maka bolehlah ia makan harta itu menurut yang patut. Kemudian apabila kamu menyerahkan harta kepada mereka, maka hendaklah kamu adakan saksi-saksi (tentang penyerahan itu) bagi mereka. Dan cukuplah Allah sebagai Pengawas (atas persaksian itu)., 37

Pemeliharaan harta anak yatim ketika belum mampu memelihara harta merupakan wujud kepedulian terhadap kehidupan mereka. Apabila anak yatim langsung memperoleh harta ketika belum mampu mengelolanya, dikhawatirkan harta tersebut akan habis dan masa depan anak tersebut akan hancur. Oleh karena itu harus ada orang yang bertanggung jawab menjaga harta tersebut dan mengembalikan apabila mereka telah mampu untuk mengelolanya sendiri. Sedangkan anak yatim yang tidak mempunyai harta harus dijaga sebagai tanggung jawab bersama. Mereka tidak boleh dibiarkan kelaparan, tinggal dijalan. Mereka harus diayomi supaya bisa mendapatkan kehidupan yang baik setelah kepergian orang tuanya.

\footnotetext{
${ }^{36}$ QS. Al-Maun 107: 1-7

${ }^{37}$ QS An-Nisa:6
} 
110 Masrul Effendi Umar Harahap, Pemberdayaan Dalam Perspektif Al-Quran Jurnal At-Taghyir : Jurnal Dakwah dan Pengembangan Masyarakat Desa

Volume 2 Nomor 1 Desember 2019, h. 97-112

6. Pemberdayaan Masyarakat melalui Zakat

Zakat adalah solusi yang ditawarkan oleh al-Quran dalam memberdayakan masyarakat. Zakat memiliki misi redistribusi aset, sirkulasi kekayaan yang seimbang, serta pada akhirnya akan mewujudkan pemerataan ekonomi. Zakat adalah ibadah maliah-ijtimaiyah yang memiliki fungsi strategis dalam pembangunan ekonomi umat. Berikut ini metode al-Quran dalam mengoptimalkan peran zakat dalam masyarakat,

a. Motivasi untuk melaksanakan kewajiban zakat

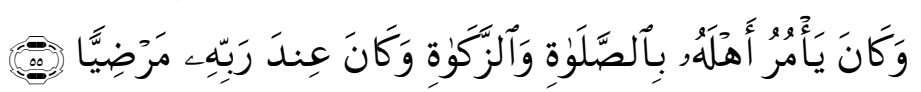

"Dan ia menyuruh ahlinya untuk bersembahyang dan menunaikan zakat, dan ia adalah seorang yang diridhai di sisi Tuhannya., 38

b. Metode Pelaksanaan Zakat

$$
\text { و إبما الصدقات للفقراء و المساكين و العاملين عليها و المؤلفة قلوبهم وفي الرقاب و الغارمين وفي سبيل الله }
$$

"Sesungguhnya zakat-zakat itu, hanyalah untuk orang-orang fakir, orang-orang miskin, pengurus-pengurus zakat, para muallaf yang dibujuk hatinya, untuk (memerdekakan) budak, orang-orang yang berutang, untuk jalan Allah dan orang-orang yang sedang dalam perjalanan, sebagai sesuatu ketetapan yang diwajibkan Allah; dan Allah Maha Mengetahui lagi Maha Bijaksana."39

Ayat ini dikuatkan oleh hadits dari Rasulullah Saw.

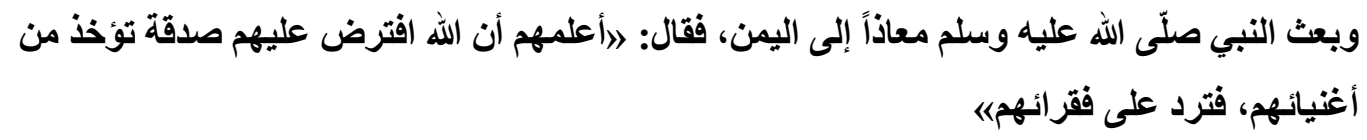

"Rasulullah Saw. Telah mengutus Muadz ke Yaman, Maka beliau bersabda : Ajarilah mereka bahwasanya Allah telah mewajibkan zakat terhadap mereka, berasal dari yang kaya dari mereka, kemudian dikembalikan terhadap orang-orang fakir dari mereka.,

c. Ancaman bagi orang yang meninggalkan zakat

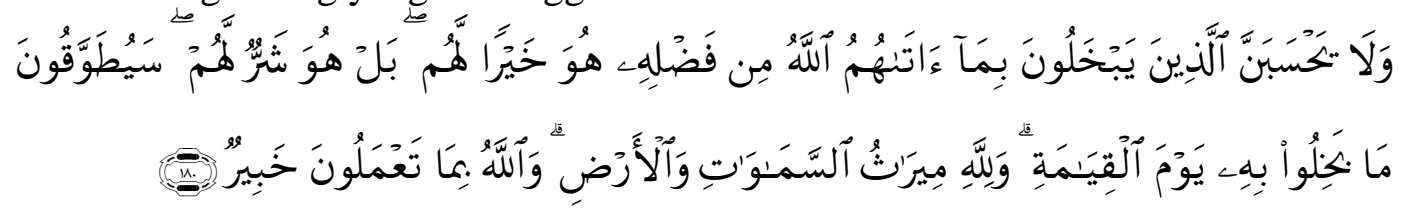

"Sekali-kali janganlah orang-orang yang bakhil dengan harta yang Allah berikan kepada mereka dari karuniaNya menyangka, bahwa kebakhilan itu baik bagi mereka. sebenarnya kebakhilan itu adalah buruk bagi mereka. harta yang mereka bakhilkan itu

\footnotetext{
${ }^{38}$ QS. Maryam: 55

${ }^{39}$ QS At-Taubah: 60

${ }^{40}$ Wahbah Zuhaili, Fiqh al-Islami wa Adillatuhu, (Damaskus: Dar el-Fikri, 2007M), hlm. 1803,
} Jilid III 
111 Masrul Effendi Umar Harahap, Pemberdayaan Dalam Perspektif Al-Quran Jurnal At-Taghyir : Jurnal Dakwah dan Pengembangan Masyarakat Desa

Volume 2 Nomor 1 Desember 2019, h. 97-112

akan dikalungkan kelak di lehernya di hari kiamat. dan kepunyaan Allah-lah segala warisan (yang ada) di langit dan di bumi. dan Allah mengetahui apa yang kamu kerjakan."

Al-Quran sangat memperhatikan kaum muslimin. Al-Quran mengharapkan kaum muslimin menjadi umat yang tangguh dari keseluruhan sisi kehidupan sehingga tercipta masyarakat madani (civil society) yang kuat dan sejahtera. Seperti yang digambarkan oleh Syed Naquib al-Attas bahwa masyarakat madani yaitu masyarakat yang berperadaban, merujuk kepada masyarakat yang hidup pada zaman Rasulullah Saw di Madinah. ${ }^{42}$ Sekarang yang menjadi tanggung jawab kita adalah bagaimana cara mengamalkan ajaran islam yang sesungguhnya. Umat Islam harus berilmu supaya memiliki potensi untuk memajukan dirinya.

\section{Penutup}

Permasalahan sosial yang telah lama terjadi dan terus berlanjut hingga saat ini. Berbagai permasalahan yang muncul terus menimbulkan berbagai spekulasi. Berbagai konsep pembangunan telah dilaksanakan tetapi masih banyak masyarakat yang terjebak dalam kondisi yang sama, seperti pengangguran, kemiskinan, permasalahan kesehatan dan beragam masalah sosial yang lainnya. Salah satu konsep yang ditawarkan adalah pemberdayaan masyarakat. Pemberdayaan masyarakat sebagai suatu usaha yang digambarkan dalam berbagai bentuk kegiatan yang nyata ditengah masyarakat. Tujuannya menyadarkan masyarakat agar dapat menggunakan serta memilih kehidupannya untuk mencapai tingkat hidup yang lebih baik dalam segala segi kehidupan. Pemberdayaan juga dikaji didalam Al-Qur'an salah satunya melalui dakwah. Ada 4 fungsi dakwah yang berkenaan dengan pemberdayaan, yaitu: i'tiyadi, muharriq, iqaf, dan tahrif. Dakwah sebagai salah satu jalan dalam upaya pemberdayaan masyarakat, memiliki banyak keunggulan karena tidak mengkaji dari sudut pandang agama saja, tetapi mengkaji dari berbagai sumber yang bisa dipergunakan. Pemberdayaan dalam al-Quran diantaranya meliputi bidang ekonomi seperti melalui infak, zakat, sedekah, pemberdayaan lingkungan, pendidikan, sosial, lingkungan dan sebagainya. Islam mengajarkan umatnya melalui al-Qur'an. Islam mengajarkan

${ }^{41}$ QS. Al-Imran: 180

42 Asykuri, dkk, Pendidikan Kewarganegaraan Menuju Kehidupan yang Demokratis dan Berkeadaban, ( Yogyakarta: Majelis Pendidikan Tinggi dan Penelitian Pimpinan Pusat Muhammadiyah, t.th), hlm. 23 
112 Masrul Effendi Umar Harahap, Pemberdayaan Dalam Perspektif Al-Quran Jurnal At-Taghyir : Jurnal Dakwah dan Pengembangan Masyarakat Desa

Volume 2 Nomor 1 Desember 2019, h. 97-112

umatnya untuk saling menjaga, menguatkan, mendidik untuk kehidupan dunia dan kebahagian akhirat.

\section{Daftar Kepustakaan}

Al-Sa idi, Abdullah, Taisir Karimir Rahman, Cairo: Muassasah Risalah, 2000

Abu Ja`far, Jamiul Bayan fi Tafsiril Quran. Cairo: Muassasah Risalah, 2000.

Affizal Ahmad, kepentingan Pendidikan dalam Pembentukan Kualitas Hidup Sejahtera, (Malaysia : Universiti Sains Malaysia, 2010.

Al-Maraghi, Mustafa, Tafsir Al-Maraghi, Mesir : Maktabah Halabi, 1946.

Asep Saiful Muhtadi dan Agus Ahmad Safe'i, Metodologi Penelitian Dakwah. Bandung, Pustaka Setia, 2003.

Asykuri dkk, Pendidikan Kewarga Negaraan Menuju Kehidupan Yang Demokratis dan Berkeadaban, Yogyakarta : Majelis Pendidikan Tinggi dan Penelitian Pimpinan Pusat Muhammadiyah, 2007.

Aziz, Jama`ah Amin Abdul, Wasiat Qurani Aktivis Dakwah. Jogjakarta: Uswah, 2007.

Hikamat, Harry, Strategi Pemberdayaan Masyarakat, Bandung : Humaniora

KBBI v1.1.

M. Qureish Shihab, Membumikan Al-Qur'an:Fungsi dan peran wahyu Dalam Masyarakat, Bandung : Mizan, 2004.

Mansour Fakih, Dakwah Siapa Yang di Untungkan, Jakarta:P3M pesantren No.04/Vol/1987.

Martono, Nanang, Sosiologi Perubahan Social Perspektif Klasik, Modern, Postmodern, dan Psikologi. Jakarta: PT. RajaGrafindo, 2011.

Muhammad Sulthon, Desain Ilmu Dakwah, Kajian Ontologis, Epistemologis dan Aksiologis, Semarang : Wali Songo Press, 2003.

Ali Mukti, Agama Dalam Pergumulan Masyarakat Kontemporel, Yogyakarta : Tiara Wacana Yogya, 1998.

Musthafa al Maraghi, Tafsir al-Maraghi, Mesir: Maktabah Halabi, 1946.

Shihab Quraish, Tafsir Al-Misbah, Jakarta : Lentera Hati, 2005.

Qurthubi, Imam, Aljami` li Ahkamil Quran. Cairo: Darul Kutub al Misriyah, 1964

Quthb Sayyid, fi Zhilalili Quran, Beirut : Dar Syurq, 1412H.

Wrihatnolo, Randhy R. Manajemen Pemberdayaan. Jakarta: PT Elex Media Komputindo. 2007.

Soelaiman Munandar, Ilmu sosial dasar, Bandung: PT. Eresco, 1993.

Zuhaily Wahbah, Tafsir al-Washit Jilid II. Damaskus: Darul Fikri, 1422 H. 